\title{
Assessment of Trihalomethane Formation in Chlorinated Raw Waters with Differential UV Spectroscopy Approach
}

\author{
Kadir Özdemir, ${ }^{1}$ İsmail Toröz, ${ }^{2}$ and Vedat Uyak ${ }^{3}$ \\ ${ }^{1}$ Department of Environmental Engineering, Bulent Ecevit University, Incivez, 67100 Zonguldak, Turkey \\ ${ }^{2}$ Department of Environmental Engineering, Istanbul Technical University, Maslak, 34469 Istanbul, Turkey \\ ${ }^{3}$ Department of Environmental Engineering, College of Engineering, Pamukkale University, Kinikli, 20020 Denizli, Turkey \\ Correspondence should be addressed to Kadir Özdemir; kadirozdemir73@yahoo.com
}

Received 26 September 2013; Accepted 27 October 2013

Academic Editors: M. Kumar and K. Kuroda

Copyright (C) 2013 Kadir Özdemir et al. This is an open access article distributed under the Creative Commons Attribution License, which permits unrestricted use, distribution, and reproduction in any medium, provided the original work is properly cited.

\begin{abstract}
In this study, the changes in UV absorbance of water samples were characterized using defined differential UV spectroscopy (DUV), a novel spectroscopic technique. Chlorination experiments were conducted with water samples from Terkos Lake (TL) and Büyükçekmece Lake (BL) (Istanbul, Turkey). The maximum loss of UV absorbance for chlorinated TL and BL raw water samples was observed at a wavelength of $272 \mathrm{~nm}$. Interestingly, differential absorbance at $272 \mathrm{~nm}\left(\Delta U V_{272}\right)$ was shown to be a good indicator of UV absorbing chromophores and the formation of trihalomethanes (THMs) resulting from chlorination. Furthermore, differential spectra of chlorinated TL waters were similar for given chlorination conditions, peaking at $272 \mathrm{~nm}$. The correlations between THMs and $\Delta U_{272}$ were quantified by linear equations with $R^{2}$ values $>0.96$. The concentration of THMs formed when natural organic matter is chlorinated increases with increasing time and $\mathrm{pH}$ levels. Among all THMs, $\mathrm{CHCl}_{3}$ was the dominant species forming as a result of the chlorination of TL and $\mathrm{BL}$ raw water samples. The highest chloroform $\left(\mathrm{CHCl}_{3}\right)$, dichlorobromomethane $\left(\mathrm{CHCl}_{2} \mathrm{Br}\right)$, and dibromochloromethane $\left(\mathrm{CHBr}_{2} \mathrm{Cl}\right)$ concentration were released per unit loss of absorbance at $272 \mathrm{~nm}$ at $\mathrm{pH} 9$ with a maximum reaction time of 168 hours and $\mathrm{Cl}_{2}$ /dissolved organic carbon ratio of 3.2.
\end{abstract}

\section{Introduction}

Disinfection of surface water supplies containing natural organic matter (NOM) with chlorine leads to formation of chlorinated brominated, and in much smaller levels, iodinated by-products defined as disinfection by-products (DBPs) [1-3]. Trihalomethanes (THMs) and halo acetic acids (HAAs) are the main groups of DBPs commonly found in drinking waters [4-7]. Such hazardous compounds have been shown to be related to the occurrence of cancer, growth retardation, spontaneous abortion, and congenital cardiac effects [8-13]. Therefore, strict regulations for water quality have been recently imposed in some European countries [14]. These regulations should ensure the safety of drinking water through the elimination (or reduction to a minimum concentration) of the hazardous substances in water. The maximum contaminant level of THMs was set to $80 \mu \mathrm{g} / \mathrm{L}$ by United States Environmental Protection Agency (USEPA) [15]. Whereas the European Union (EC) has set the THMs limit to $100 \mu \mathrm{g} / \mathrm{L}$ [16]. The THMs limit in Turkey is also $100 \mu \mathrm{g} / \mathrm{L}[17]$.

The relationships among chlorination conditionals such as $\mathrm{pH}$, temperature, reaction time, bromide concentration, chlorine dosage and NOM concentration, and the formation of DBPs are highly nonlinear and complex [18]. Developing formal kinetic or statistical models for DBP formation currently requires substantial cost and effort associated with analysis of DBPs, thus restricting the amount of data that can be obtained from any single laboratory or field study of the chlorination reactions and limiting the availability of information that may be useful in formulating or testing models of the reaction sequence [19]. Several researches have attempted to correlate water quality parameters to DBP formation in an effort to find a useful surrogate parameter to 
predict DBP formation or to better understand the chemical nature of DBP formation processes [20-22]. The use of surrogate parameters to monitor formation of chlorinated by-products can be used as an alternative to mechanistic or statistical models for estimating DBPs formation. Many surrogate parameters that have been most widely used to estimate DBP formation potential (DBPFP) include ultraviolet absorbance (UV), specific UV absorbance (SUVA), which is UV absorbance divided by dissolved organic carbon (DOC) concentration and DOC. It was reported that the correlation between UV absorbance at $254 \mathrm{~nm}\left(\mathrm{UV}_{254}\right)$ wavelength and the THM formation potential (THMFP) was strong [23].

Since SUVA is strongly correlated with the aromaticity and reactivity of $\mathrm{NOM}$, it has been used extensively as a conventional parameter $[24,25]$ and can therefore be used to estimate the concentration of NOM moieties in a water sample.

It has been reported that simple and reliable relationships existed between change in UV absorbance of NOM and formation of DBPs during the chlorination processes $[21,26-$ 28]. As the aromatic functional groups are thought to be both dominant chromospheres in NOM and the dominant sites of attack by chlorine on NOM molecules, $\mathrm{UV}_{254}$ has frequently been proposed to predict the concentration of DBP precursors. Although the use of UV spectroscopy to estimate DBP formation is problematic, a technique known as differential UV spectroscopy (DUV) has been developed [29]. $\triangle \mathrm{UV}$ has been shown to be an effective spectrophotometric method for monitoring the amount of DBPs formed by chlorination of NOM. This approach focuses on the change in UV absorbance caused by the chlorination reaction, rather than the overall UV spectrum of water. The differential UV spectrum of chlorinated NOM is defined as shown in

$$
\Delta \mathrm{UV}_{\lambda}=\mathrm{UV}_{\lambda}^{\text {chlorinated }}-\mathrm{UV}_{\lambda}^{\text {inital }}
$$

where $\mathrm{UV}_{\lambda}^{\text {inital }}$ is the UV absorbance at wavelength $\lambda$ prior to chlorination, $\mathrm{UV}_{\lambda}^{\text {chlorinated }}$ is the UV absorbance at wavelength $\lambda$ after chlorination, and $\Delta \mathrm{UV}_{\lambda}$ is the differential UV absorbance at wavelength $\lambda$.

As the chlorination reaction with NOM occurs primarily at sites that absorb UV light, DUV could provide a sensitive and highly specific probe for chlorination reactions. Moreover, the magnitude of decrease in UV absorbance at $272 \mathrm{~nm}$ $\left(\Delta U_{272}\right)$ was found to be an excellent indicator of total organic halogen formation resulting from chlorination, independent of chlorine to DOC ratio, bromide concentration, $\mathrm{pH}$, reaction time, and NOM source $[21,30,31]$.

In this study, we investigated the applicability of differential absorbance to quantify the reactivity of NOM from raw waters.

\section{Materials and Methods}

2.1. Sample Collection. During this study, water samples were taken from Terkos and Büyükçekmece Lakes in Istanbul, Turkey. Samples were collected during the summer period (June, July, and August) in 2010. Terkos Lake (TL) and Büyükçekmece Lake (BL) are the main surface water sources of Istanbul, providing nearly 1 million $\mathrm{m}^{3}$ raw water to the drinking water treatment plants of Kağıthane and Büyükçekmece. The characteristics of raw water quality parameters are presented in Table 1. Raw water samples were collected as grab samples and stored in a refrigerator at $4^{\circ} \mathrm{C}$ to retard biological activity.

2.2. Chlorination Procedure. Chlorination of raw water samples was conducted in accordance with Standard Methods 5710 B [32]. Before chlorination, sample $\mathrm{pH}$ values were adjusted to $\mathrm{pH} 5,7$, and 9 by addition of $\mathrm{HCl}$ or $\mathrm{NaOH}$ solution. The chlorinated samples were placed into $125 \mathrm{~mL}$ amber glass bottles with polypropylene screw caps and TFEfaced septa. Raw water samples were chlorinated to $\mathrm{Cl}_{2} / \mathrm{DOC}$ ratios of $0.8,1.6$, and 3.2 before incubation in the dark for either $1,4,24,48,96$, or 168 hours. After the reaction periods, chlorine residual concentrations were determined with DPD ferrous titrimetric method according to Standard Methods $4500 \mathrm{Cl}-\mathrm{F}$ [32]. Sodium sulfite solution was used as a quenching agent for all chlorinated samples prior to UV spectrophotometric and THM analyses.

2.3. Analytical Procedure. THM measurements were performed by liquid-liquid extraction (LLE) with n-pentane. For THMs, a total of six THM calibration standards were prepared using certificated commercial mix solutions (Accu Standard, Inc., purity $>99 \%$ ). Samples were analyzed by gas chromatography (GC) equipped with a microelectron capture detector $(\mu \mathrm{ECD})$ for THM analyses. A capillary column of (DB-1 J\&W Science) $30 \mathrm{~m} \times 0.32 \mathrm{~mm}$ and $1.0 \mu \mathrm{m}$ film thickness was used. Samples were injected in split/splitless mode with helium as a carrier gas and nitrogen gas as a make-up gas. The minimum quantification limits for THM species ranged between 0.5 and $1 \mu \mathrm{g} / \mathrm{L}$. DOC concentrations were measured on a Schimadzu 5000 total carbon analyzer equipped with an AS auto sampler according to method 5310 B in Standard Methods [32]. The instrument provided reliable, accurate, and reproducible data with a minimum detection limit of $2 \mu \mathrm{g} / \mathrm{L}$. The UV absorbance readings between wavelengths of 250 and $410 \mathrm{~nm}$ were determined using a Shimadzu 1608 UV/VIS spectrophotometer.

\section{Result and Discussion}

3.1. Differential UV Spectra of Chlorinated NOM. The changes of UV absorbance spectra for TL and BL water samples, including NOM before and after chlorination, are shown in Figure 1. The UV absorbance values of TL and BL water samples at given wavelengths $(250-400 \mathrm{~nm})$ are significantly decreased for different reaction times $(1,4,12,96$, and 168 hours) after chlorination. For instance, the UV absorbance of TL raw water samples at a wavelength of $272 \mathrm{~nm}$ was reduced from 0.095 to $0.06 \mathrm{~cm}^{-1}$ by $1 \mathrm{~h}$ chlorination. Whereas the UV absorbance of BL raw water samples at the same wavelength decreased from 0.064 to $0.032 \mathrm{~cm}^{-1}$ by $1 \mathrm{~h}$ after chlorination.

The similar trend with corresponding to UV spectra of chlorinated TL and BL raw water samples was determined at the range of $250-400 \mathrm{~nm}$ for the desired reaction times. The 
TABLE 1: Raw water quality parameters.

\begin{tabular}{lccc}
\hline Parameter & Unit & Terkos Lake & Büyükçekmece Lake \\
\hline $\mathrm{pH}$ & & & Average value \\
Turbidity & - & $7.97 \pm 0.16$ & $8.19 \pm 0.14$ \\
Total Hardness & $\mathrm{NTU}$ & $3.34 \pm 0.46$ & $3.24 \pm 0.27$ \\
Alkalinity & $\mathrm{mg} \mathrm{CaCO} / \mathrm{L}$ & $116.3 \pm 6.7$ & $166.4 \pm 10.3$ \\
Temperature & $\mathrm{mg} \mathrm{CaCO}_{3} / \mathrm{L}$ & $103.1 \pm 7.53$ & $114 \pm 7.7$ \\
DOC & ${ }^{\circ}$ & $17.2 \pm 2.3$ & $17.1 \pm 2.1$ \\
UV254 & $\mathrm{mg} / \mathrm{L}$ & $4.78 \pm 0.3$ & $4.71 \pm 0.45$ \\
Br & $\mathrm{cm}^{-1}$ & $0.13 \pm 0.01$ & $0.095 \pm 0.008$ \\
DBPFP & $\mu \mathrm{g} / \mathrm{L}$ & $90 \pm 20$ & $180 \pm 20$ \\
Conductivity & $\mu \mathrm{g} / \mathrm{L}$ & $278 \pm 30.2$ & $230 \pm 24.4$ \\
SUVA & $\mu \mathrm{S} / \mathrm{cm}$ & $305 \pm 13.5$ & $470 \pm 16$ \\
\hline
\end{tabular}

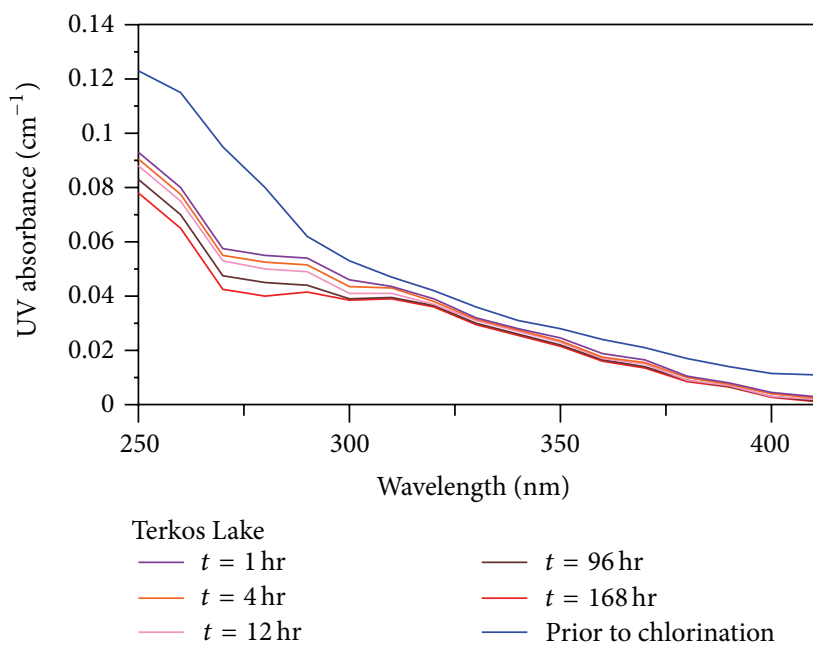

(a)

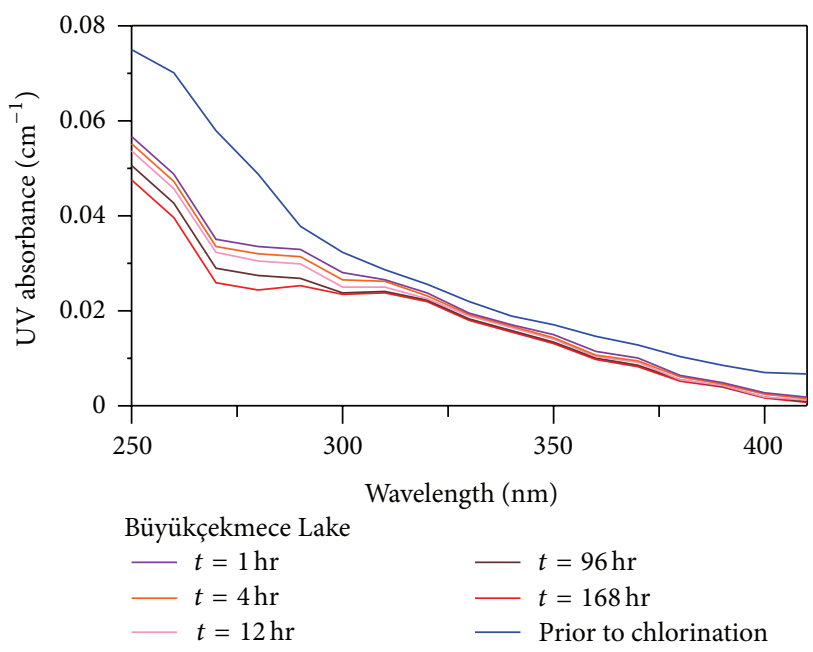

(b)

FIGURE 1: Chlorinated UV absorbance spectra at varying reaction times and at $\mathrm{pH} 7$ for (a) TL water samples and (b) BL water samples.

maximum loss of UV absorbance in TL and BL water samples was recorded at $400 \mathrm{~nm}$ and $168 \mathrm{~h}$ reaction time, reaching 0.0012 and $0.001 \mathrm{~cm}^{-1}$, respectively. The ratio of decreasing UV absorbance of chlorinated water samples containing NOM followed consistent pattern as a function of wavelength and at a given reaction time.

Changes in the UV spectrum of chlorinated NOMcontaining TL and BL raw water samples are presented with differential absorbance spectrum between 250 and $400 \mathrm{~nm}$ (Figure 2).

The measurement of differential UV spectrum of TL and $\mathrm{BL}$ raw water samples was characterized using (1). These findings demonstrate several shared properties of the differential spectra. The sign of differential absorbance was always negative at $250-400 \mathrm{~nm}$ wavelengths because the UV absorbance of NOM surface water supplies decreased with chlorination. The differential spectra of chlorinated TL and
BL raw water samples consistently peak at $272 \mathrm{~nm}$. In fact, $272 \mathrm{~nm}$ was the maximum differential absorbance for all chlorinated TL and BL raw water samples at all reaction times. The TL and BL differential absorbance values of water samples at $272 \mathrm{~nm}$ at a reaction time of $4 \mathrm{~h}$ were 0.04 and $0.0285 \mathrm{~cm}^{-1}$, respectively. The highest $\Delta \mathrm{UV}_{272}$ values were observed at a reaction time of $168 \mathrm{~h}\left(0.0525\right.$ and $0.04 \mathrm{~cm}^{-1}$ for TL and BL samples, resp.), demonstrating that the magnitude of the differential spectra developed with increasing chlorination reaction time, and is consistent with the results of other studies [28, 29, 33].

We also found that the differential spectrum of chlorinated TL and $\mathrm{BL}$ water including NOM was related to other independence parameters of water quality and chlorination conditions. Furthermore, these spectra exhibited a peak at $272 \mathrm{~nm}$, suggesting that differential absorbance is an effective spectrophotometric parameter providing insight into the 


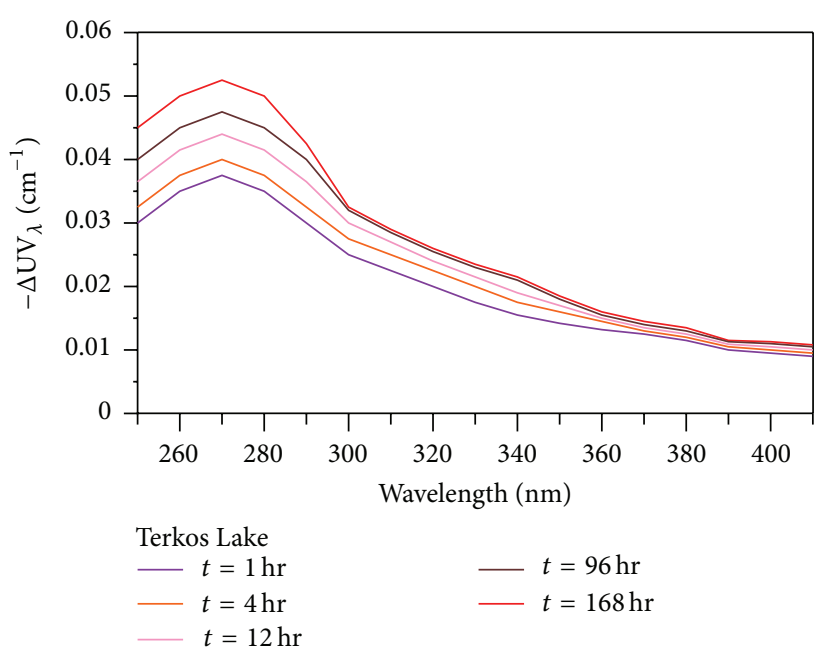

(a)

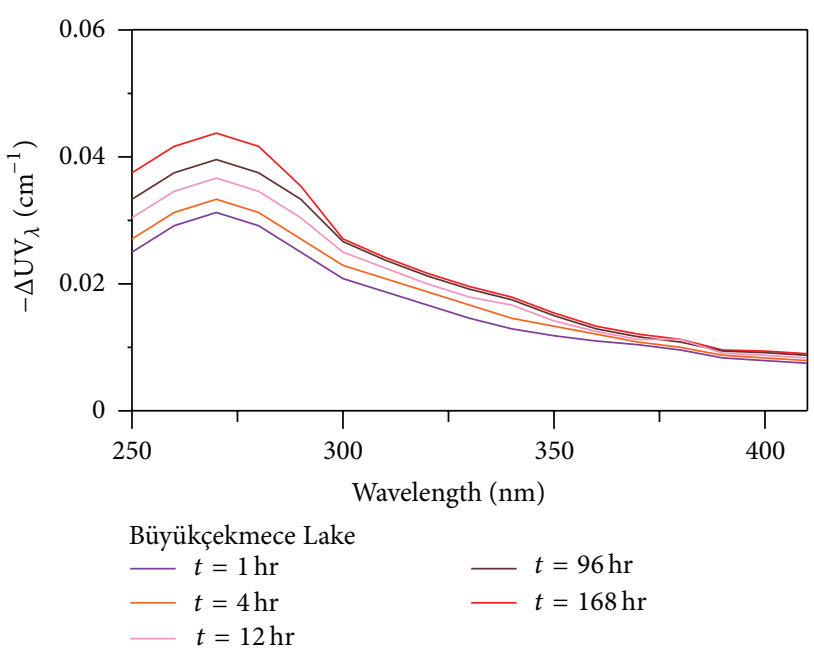

(b)

FIgURE 2: Differential spectra at varying reaction times and at $\mathrm{pH} 7$ for (a) TL water samples and (b) BL water samples.

reactivity of NOM molecules with regard to the formation of DBPs such as THMs. An observation was also made in previous publications $[21,31,34,35]$.

3.2. Relationship between $\Delta U V_{272}$ and THM Concentrations. A series of experiments were conducted upon TL and BL water samples to examine THM formation at three $\mathrm{Cl}_{2} / \mathrm{DOC}$ ratios $(0.8,1.6$, and 3.2), for the chlorination $\mathrm{pH}(\mathrm{pH}=7)$ and at reaction times from $1 \mathrm{~h}$ to $168 \mathrm{~h}$. We identified strong correlations between total THM (TTHM) concentrations and $\Delta \mathrm{UV}_{272}$ values obtained by the chlorination of TL raw waters (Figure 3).

These correlations were modeled by linear regression analysis with $R^{2}$ values $>0.98$ given by the following.

TL waters

$$
\operatorname{TTHM}(\mu \mathrm{g} / \mathrm{L})=4952.2 \Delta \mathrm{UV}_{272}-25.12 .
$$

$\mathrm{BL}$ raw waters

$$
\operatorname{TTHM}(\mu \mathrm{g} / \mathrm{L})=4339.5 \Delta \mathrm{UV}_{272}-3.08 \text {. }
$$

The highest TTHM content and $\Delta \mathrm{UV}_{272}$ value $\left(395.62 \mu \mathrm{g} / \mathrm{L}\right.$ and $0.079 \mathrm{~cm}^{-1}$, resp.) were obtained for the chlorinated TL raw water samples with the SUVA level of $3.04 \mathrm{~L} / \mathrm{mg} \cdot \mathrm{m}$, at the maximum $\mathrm{Cl}_{2} / \mathrm{DOC}$ ratio (3.2) and reaction time $(168 \mathrm{~h})$. The relationship between hydrophobic SUVA and the formation of TTHM is dependent on the activated aromatic structures which are the major components in NOM. In high SUVA water (e.g., TL raw water), high chlorine reactivity resulted in the formation of more THMs than in low SUVA level waters (e.g., BL raw water that has hydrophilic organic fractions).

3.3. The Effects of $p H$, Reaction Time, and Chlorine Dose on THMs Formation. Solution $\mathrm{pH}$ has a significant effect on the speciation and amount of THM forming as a result of chlorination. We found that higher $\mathrm{pH}$ resulted in increased THM concentrations for the two surface water sources studied. $\mathrm{CHCl}_{3}$, dichlorobromomethane $\left(\mathrm{CHCl}_{2} \mathrm{Br}\right)$, and dibromochloromethane $\left(\mathrm{CHBr}_{2} \mathrm{Cl}\right)$ are common THM compounds in chlorinated $\mathrm{TL}$ and $\mathrm{BL}$ raw waters. The concentrations of $\mathrm{CHCl}_{3}$ generated in chlorinated TL and $\mathrm{BL}$ raw waters, as estimated by $\Delta \mathrm{UV}_{272}$ and at $\mathrm{pHs} 5,7$, and 9 are shown in Figure 4.

The relationship between $\mathrm{CHCl}_{3}$ concentrations and $\Delta \mathrm{UV}_{272}$ could be well fitted by a straight line $\left(R^{2}>0.98\right)$. As the $\mathrm{pH}$ increased for each raw water source, more $\mathrm{CHCl}_{3}$ was formed per unit of UV absorbance destroyed. Furthermore, the highest $\mathrm{CHCl}_{3}$ concentration and $\Delta \mathrm{UV}_{272}$ absorbance value $\left(222.55 \mu \mathrm{g} / \mathrm{L}\right.$ and $0.0865 \mathrm{~cm}^{-1}$, resp.) were measured at the highest $\mathrm{pH}$ level tested (TL water, $\mathrm{pH} 9, \mathrm{Cl}_{2} / \mathrm{DOC}$ 3.2 , and $168 \mathrm{~h}$ reaction time). Whereas the lowest $\mathrm{CHCl}_{3}$ concentration and $\Delta \mathrm{UV}_{272}$ value $\left(67.16 \mu \mathrm{g} / \mathrm{L}\right.$ and $0.059 \mathrm{~cm}^{-1}$, resp.) were measured at the most acidic $\mathrm{pH}$ (BL water, $\mathrm{pH}$ $5, \mathrm{Cl}_{2} / \mathrm{DOC} 3.2,168 \mathrm{~h}$ reaction time). This can be explained using the mechanism of DBPs formation as described by Reckhow and Singer [36]. According to this mechanism, base-catalyzed hydrolysis prevails under alkaline conditions, resulting in more $\mathrm{CHCl}_{3}$ at $\mathrm{pH} 9$, relative to acidic conditions ( $\mathrm{pH}$ 5). Although $\mathrm{CHCl}_{3}$ formation to $\Delta \mathrm{UV}_{272}$ regression lines did not pass through the origin for all $\mathrm{pHs}$ studied, this can be explained by some initial reactions between NOM and $\mathrm{Cl}_{2}$. These reactions demolish the aromaticity of activated functional groups and produce chlorinated intermediates before $\mathrm{CHCl}_{3}$ formation $[29,37,38]$. $\mathrm{CHCl}_{2} \mathrm{Br}$ and $\mathrm{CHBr}_{2} \mathrm{Cl}$ were the other major THMs identified in chlorinated TL and $\mathrm{BL}$ raw waters. The concentrations of $\mathrm{CHCl}_{2} \mathrm{Br}$ and $\mathrm{CHBr}_{2} \mathrm{Cl}$ were also found to increase with increasing $\mathrm{pH}$ levels with the highest $\mathrm{CHCl}_{2} \mathrm{Br}$ and $\mathrm{CHBr}_{2} \mathrm{Cl}$ concentrations (39.72 and $19.77 \mu \mathrm{g} / \mathrm{L}$ ) found at $\mathrm{pH} 9$ at $168 \mathrm{~h}$ reaction time and $\mathrm{Cl}_{2} / \mathrm{DOC}$ ratio of 3.2. Despite relatively low concentrations of $\mathrm{CHCl}_{2} \mathrm{Br}$ 


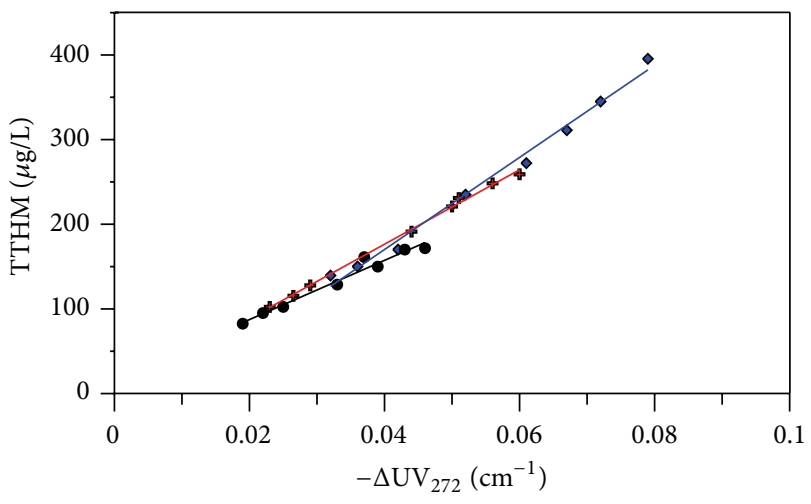

Terkos Lake

$\bullet \mathrm{Cl}_{2} / \mathrm{DOC}=0.8$

$\#+\mathrm{Cl}_{2} / \mathrm{DOC}=1.6$

$\diamond \mathrm{Cl}_{2} / \mathrm{DOC}=3.2$

(a)

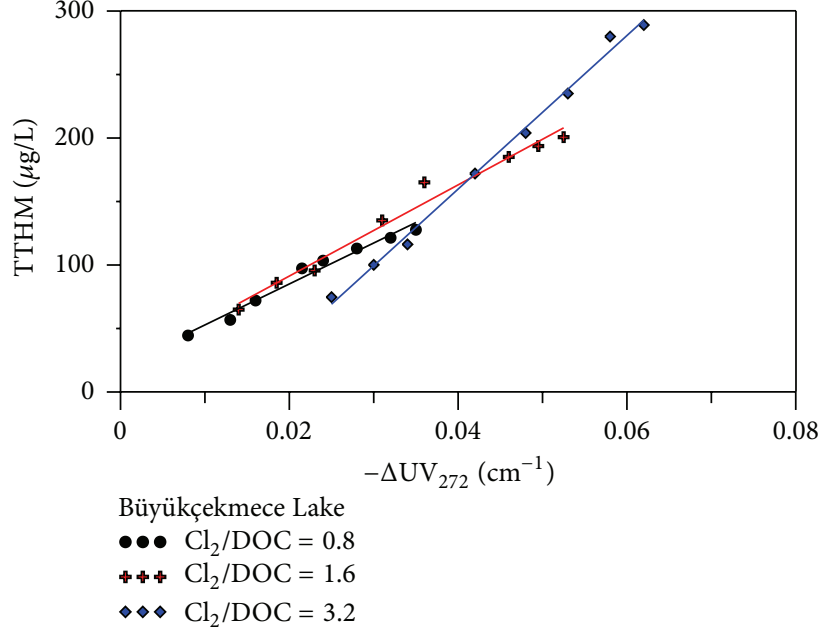

(b)

Figure 3: Correlations between $\triangle \mathrm{UV}_{272}$ values and TTHM concentrations at different $\mathrm{Cl}_{2}$ to $\mathrm{DOC}$ ratios, $\mathrm{pH}$, and reaction times from $1 \mathrm{~h}$ to seven days for (a) TL water and (b) BL water samples.

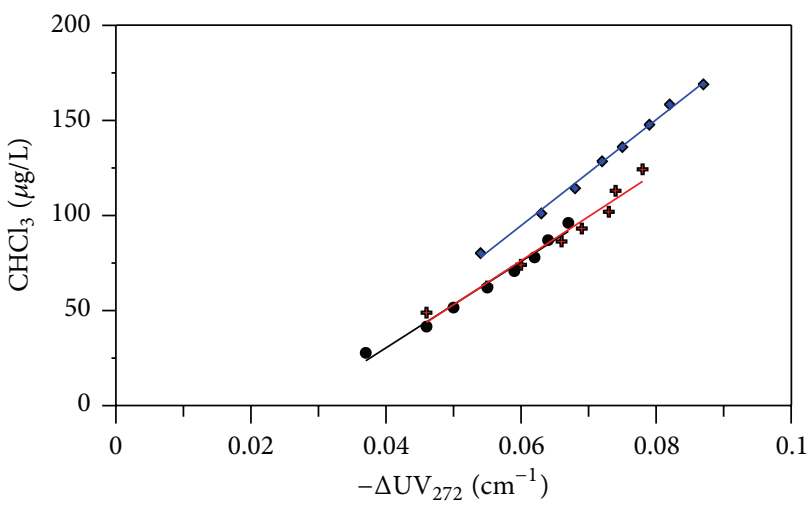

Terkos Lake

$\bullet \bullet \mathrm{pH} 5$

$+\$ \mathrm{pH} 7$

$\diamond$ pH 9

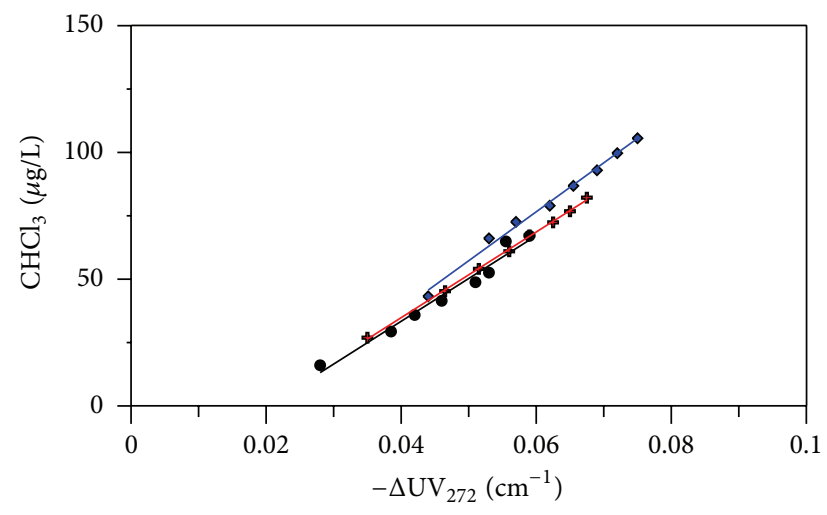

Büyükçekmece Lake

$\bullet \bullet \mathrm{pH} 5$

$\$+\mathrm{pH} 7$

$\diamond$ pH 9

(a)

(b)

Figure 4: The relationship between $\mathrm{CHCl}_{3}$ and $\Delta \mathrm{UV}_{272}$ at different $\mathrm{pH}$ (pH 5, pH7, and $\mathrm{pH}$ 9) and $\mathrm{Cl}_{2}$ to $\mathrm{DOC}$ ratios from 0.8 to 3.2 (a) in chlorinated TL water and (b) for in chlorinated BL water.

and $\mathrm{CHBr}_{2} \mathrm{Cl}$ in the chlorinated water samples, there was a strong linear correlation between $\mathrm{CHCl}_{2} \mathrm{Br}$ and $\mathrm{CHBr}_{2} \mathrm{Cl}$ and $\Delta \mathrm{UV}_{272}$ (Figures 5 and 6).

\section{Conclusion}

The chlorination of TL and BL water samples including NOM resulted in decreasing UV absorbance at all wavelengths due to the destruction of UV-absorbing chromospheres and produced characteristic UV spectra. The shape of these differential UV spectra for the chlorinated TL and BL water samples was similar for the given chlorination conditions.
In particular, the maximum loss of UV absorbance for the chlorinated raw water samples was observed at $272 \mathrm{~nm}$. This study also examined the relationships between $\Delta \mathrm{UV}_{272}$ and the formation of THMs in chlorinated waters from TL and BL water sources for Istanbul, Turkey.

The correlation between $\Delta \mathrm{UV}_{272}$ and TTHM was quantified by linear regression analysis, showing $R^{2}$ values $>0.96$. The highest TTHM and THM contents of raw water samples were observed at $\mathrm{pH} 9$ (the highest value tested).

Among the THM species formed by chlorination of the $\mathrm{TL}$ and $\mathrm{BL}$ raw water samples, $\mathrm{CHCl}_{3}$ was predominant. The highest concentrations of THM compounds, as measured 


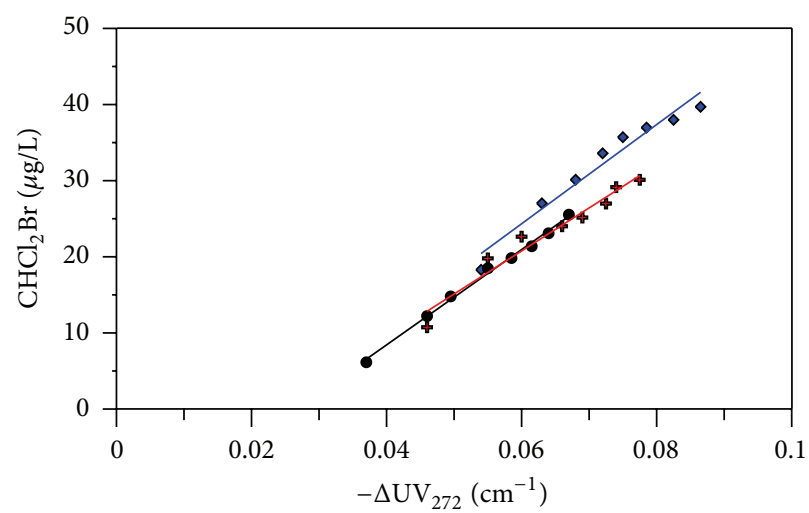

Terkos Lake

$\bullet$ pH 5

$\$+\mathrm{pH} 7$

$\diamond$ pH 9

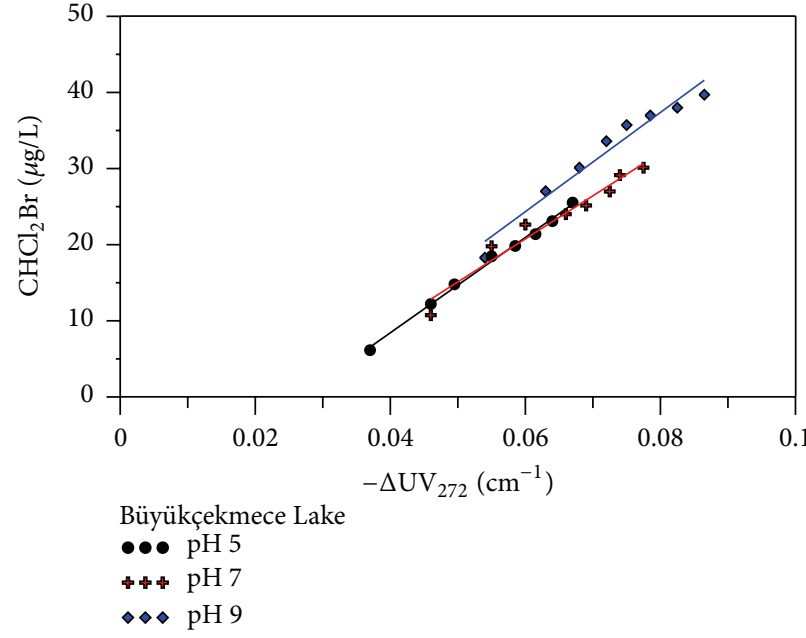

(b)

FIGURE 5: The relationship between $\mathrm{CHCl}_{2} \mathrm{Br}$ and $\Delta \mathrm{UV}_{272}$ at different $\mathrm{pH}$ ( $\mathrm{pH} 5, \mathrm{pH}$, and $\mathrm{pH}$ 9) and $\mathrm{Cl}_{2}$ to $\mathrm{DOC}$ ratios from 0.8 to 3.2 (a) for in chlorinated TL water and (b) for in chlorinated $\mathrm{BL}$ water.

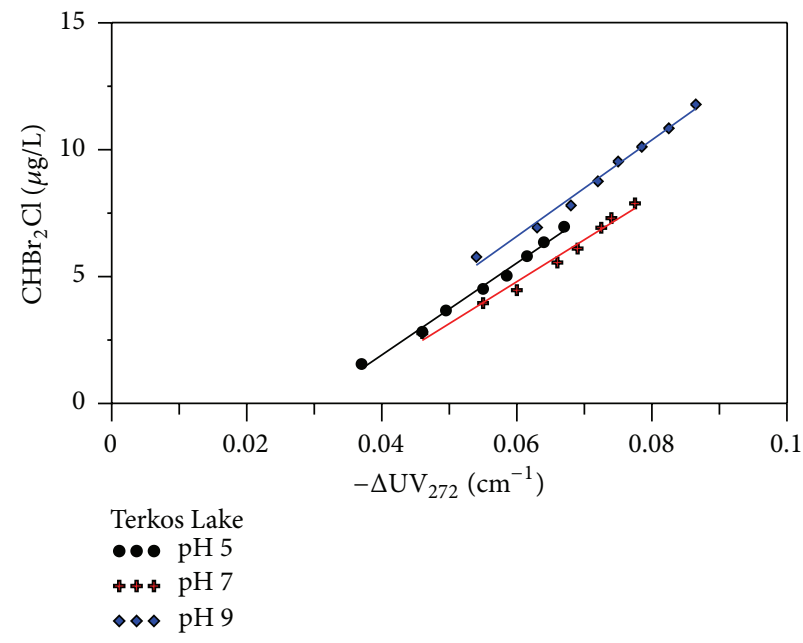

(a)

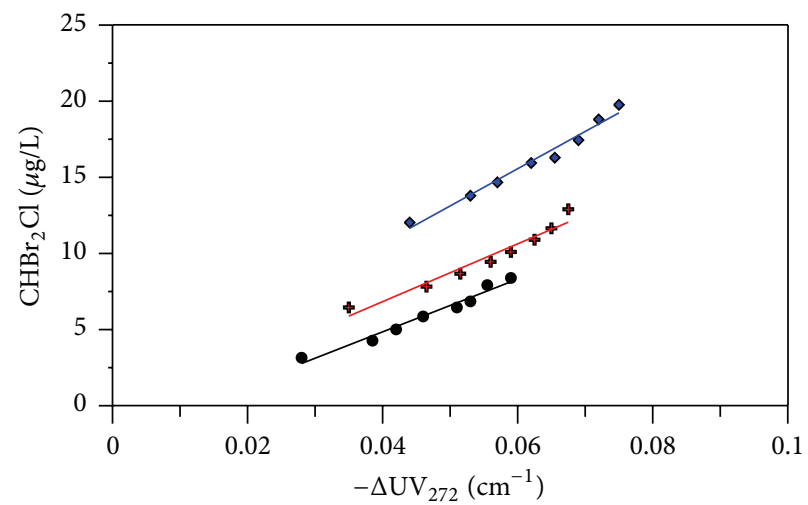

Büyükçekmece Lake

$$
\begin{array}{ll}
\bullet \text { pH } 5 \\
\leftrightarrow+4 \text { pH } 7 \\
\diamond \bullet \text { pH } 9
\end{array}
$$

Figure 6: The relationship between $\mathrm{CHClBr}_{2}$ and $\Delta \mathrm{UV}_{272}$ at different $\mathrm{pH}$ and $\mathrm{Cl}_{2}$ to DOC ratios (a) in chlorinated TL water and (b) in chlorinated BL water.

by unit loss of absorbance at $272 \mathrm{~nm}$, were produced at the highest chlorine dosage, maximum reaction time, and $\mathrm{pH} 9$.

These results demonstrate that $\Delta \mathrm{UV}_{272}$ is an alternative approach for the continuous and instantaneous monitoring of THM formation under a wide range of chlorination conditions and water qualities.

\section{Acknowledgment}

The authors would like to acknowledge the Scientific and Technological Research Council of Turkey for supporting this study as a part of scientific and technological research project with project no. of $108 \mathrm{Y} 126$.

\section{References}

[1] Y. Bichsel and U. Von Gunten, "Formation of iodotrihalomethanes during disinfection and oxidation of iodidecontaining waters," Environmental Science and Technology, vol. 34, no. 13, pp. 2784-2791, 2000.

[2] S. D. Richardson, "Drinking water disinfection by-products," in The Encyclopedia of Environmental Analysis and Remediation, R. A. Meyers, Ed., vol. 3, pp. 1398-1421, Wiley, New York, NY, USA, 1998 . 
[3] J. J. Rook, "Formation of haloforms during the chlorination of natural water," Water Treatment Exam, vol. 23, pp. 234-243, 1974.

[4] S. K. Golfinopoulos and G. B. Arhonditsis, "Multiple regression models: a methodology for evaluating trihalomethane concentrations in drinking water from raw water characteristics," Chemosphere, vol. 47, no. 9, pp. 1007-1018, 2002.

[5] J. W. Miller and P. C. Uden, "Characterization of nonvolatile aqueous chlorination products of humic substances," Environmental Science and Technology, vol. 17, no. 3, pp. 150-157, 1983.

[6] M. J. Rodriguez, J.-B. Sérodes, and P. Levallois, "Behavior of trihalomethanes and haloacetic acids in a drinking water distribution system," Water Research, vol. 38, no. 20, pp. 43674382, 2004.

[7] V. Uyak, K. Ozdemir, and I. Toroz, "Multiple linear regression modeling of disinfection by-products formation in Istanbul drinking water reservoirs," Science of the Total Environment, vol. 378, no. 3, pp. 269-280, 2007.

[8] M. I. Cedergren, A. J. Selbing, O. Löfman, and B. A. J. Källen, "Chlorination byproducts and nitrate in drinking water and risk for congenital cardiac defects," Environmental Research, vol. 89, no. 2, pp. 124-130, 2002.

[9] L. Dodds, W. King, and C. Woolcott, "Trihalomethanes in public water supplies and adverse birth outcomes," Epidemiology, vol. 10, no. 3, pp. 233-237, 1999.

[10] M. Fabbricino and G. V. Korshin, "Modelling disinfection byproducts formation in bromide-containing waters," Journal of Hazardous Materials, vol. 168, no. 2-3, pp. 782-786, 2009.

[11] I. Ivancev-Tumbas, B. Dalmacija, Z. Tamas, and E. Karlovic, "The effect of different drinking water treatment processes on the rate of chloroform formation in the reactions of natural organic matter with hypochlorite," Water Research, vol. 33, no. 18, pp. 3715-3722, 1999.

[12] R. G. Tardiff, M. L. Carson, and M. E. Ginevan, "Updated weight of evidence for an association between adverse reproductive and developmental effects and exposure to disinfection byproducts," Regulatory Toxicology and Pharmacology, vol. 45, no. 2, pp. 185-205, 2006.

[13] C.-Y. Yang, B.-H. Cheng, S.-S. Tsai, T.-N. Wu, M.-C. Lin, and K.C. Lin, "Association between chlorination of drinking water and adverse pregnancy outcome in Taiwan," Environmental Health Perspectives, vol. 108, no. 8, pp. 765-768, 2000.

[14] P. Roccaro, C. Barone, G. Mancini, and F. G. A. Vagliasindi, "Removal of natural contaminants from water supplies intended for human consumption," in Proceedings of the 9th International Conference on Environmental Science and Technology, 2005, Vol A-Oral Presentations, Pts A and B, A1268-A1273.

[15] US EPA, "National primary drinking water regulations: stage 2 disinfectants and disinfection byproducts (D/DBP)," Final Rule, vol. 68 , p. 159, 2003.

[16] EC, "EEC Council Directive 98/83/EC of 3 November 1998 on the quality of water intended for human consumption," Official Journal of the European Communities, vol. L330, no. 32, p. 51298, 1998.

[17] TMH, "Regulation concerning water intended for human consumption," Official News Paper 25730, Turkish Ministry of Health, Ankara, Turkey, 2012.

[18] G. W. Harrington, Z. K. Chowdhury, and D. M. Owen, "Developing a computer model to simulate DBP formation during water treatment," Journal of the American Water Works Association, vol. 84, no. 11, pp. 78-87, 1992.
[19] C.-W. Li, G. V. Korshin, and M. M. Benjamin, "Monitoring DBP formation with differential UV spectroscopy: a new application uses differential UV spectroscopy to monitor DBP formation easily, rapidly, and inexpensively," Journal of the American Water Works Association, vol. 90, no. 8, pp. 88-100, 1998.

[20] B. D. Black, G. W. Harrington, and P. C. Singer, "Reducing cancer risks by improving organic carbon removal," Journal of the American Water Works Association, vol. 88, no. 6, pp. 40-52, 1996.

[21] G. V. Korshin, W. W. Wu, M. M. Benjamin, and O. Hemingway, "Correlations between differential absorbance and the formation of individual DBPs," Water Research, vol. 36, no. 13, pp. 3273-3282, 2002.

[22] W. Sung, B. Reilley-Matthews, D. K. O’Day, and K. Korrigan, "Modeling if formation," Journal of the American Water Works Association, vol. 92, no. 5, pp. 53-63, 2000.

[23] J. K. Edzwald, W. C. Becker, and K. L. Wattier, "Surrogate parameters for monitoring organic matter and THM precursors," Journal of the American Water Works Association, vol. 77, no. 4, pp. 122-131, 1985.

[24] M. Kitis, T. Karanfil, J. E. Kilduff, and A. Wigton, “The reactivity of natural organic matter to disinfection by-products formation and its relation to specific ultraviolet absorbance," Water Science and Technology, vol. 43, no. 2, pp. 9-16, 2001.

[25] M. Kitis, T. Karanfil, A. Wigton, and J. E. Kilduff, "Probing reactivity of dissolved organic matter for disinfection by-product formation using XAD-8 resin adsorption and ultrafiltration fractionation," Water Research, vol. 36, no. 15, pp. 3834-3848, 2002.

[26] G. V. Korshin, C.-W. Li, and M. M. Benjamin, “The decrease of UV absorbance as an indicator of TOX formation," Water Research, vol. 31, no. 4, pp. 946-949, 1997.

[27] C. Li, M. M. Benjamin, and G. V. Korshin, “The relationship between TOX formation and spectral changes accompanying chlorination of pre-concentrated or fractionated NOM," Water Research, vol. 36, no. 13, pp. 3265-3272, 2002.

[28] P. Roccaro and F. G. A. Vagliasindi, "Differential vs. absolute UV absorbance approaches in studying NOM reactivity in DBPs formation: comparison and applicability," Water Research, vol. 43, no. 3, pp. 744-750, 2009.

[29] G. V. Korshin, C.-W. Li, and M. M. Benjamin, "Use of UV spectroscopy to study chlorination of natural organic matter," Water Disinfection and Natural Organic Matter, vol. 649, pp. 182-195, 1996.

[30] G. V. Korshin, C.-W. Li, and M. M. Benjamin, "Monitoring the properties of natural organic matter through UV spectroscopy: a consistent theory," Water Research, vol. 31, no. 7, pp. 1787-1795, 1997.

[31] P. Roccaro, H.-S. Chang, F. G. A. Vagliasindi, and G. V. Korshin, "Differential absorbance study of effects of temperature on chlorine consumption and formation of disinfection by-products in chlorinated water," Water Research, vol. 42, no. 8-9, pp. 18791888,2008 .

[32] APHA, AWWA, WEF Standard Methods for the Examination of Water and Waste Water, Washington, DC, USA, 21th edition, 2005.

[33] G. V. Korshin, M. M. Benjamin, and C.-W. Li, "Use of differential spectroscopy to evaluate the structure and reactivity of humics," Water Science and Technology, vol. 40, no. 9, pp. 9-16, 1999.

[34] G. V. Korshin and H. S. Chang, "Spectroscopic studies of the roles of distinct chromophores in NOM chlorination and DBP 
formation," in Disinfection By-Products in Drinking Water, vol. 995 of ACS Symposium Series, pp. 158-171, 2008.

[35] P. Roccaro, F. G. A. Vagliasindi, and G. V. Korshin, "Comparison of the performance of spectroscopic indices developed to quantify the halogenation of natural organic matter at varying chlorine concentrations, reaction times and temperatures," in Disinfection By-Products in Drinking Water Occurrence, Formation, Health Effects, and Control, vol. 995 of ACS Symposium Series, pp. 198-212, 2008.

[36] D. A. Reckhow and P. C. Singer, "Mechanism of organic halid formation during fulvic acid chlorination and implications with respect to preozonation," in Water Chlorination: Environmental Impact and Health Effect, vol. 5, pp. 1229-1259, Ann Arbor Science Publishes, Ann Arbor, Mich, USA, 1985.

[37] R. G. Qualls and J. D. Johnson, "Kinetics of the short-term consumption of chlorine by fulvic acid," Environmental Science and Technology, vol. 17, no. 11, pp. 692-698, 1983.

[38] N. Y. Tretyakova, A. T. Lebedev, and V. S. Petrosyan, "Degradative pathways for aqueous chlorination of orcinol," Environmental Science and Technology, vol. 28, no. 4, pp. 606-613, 1994. 

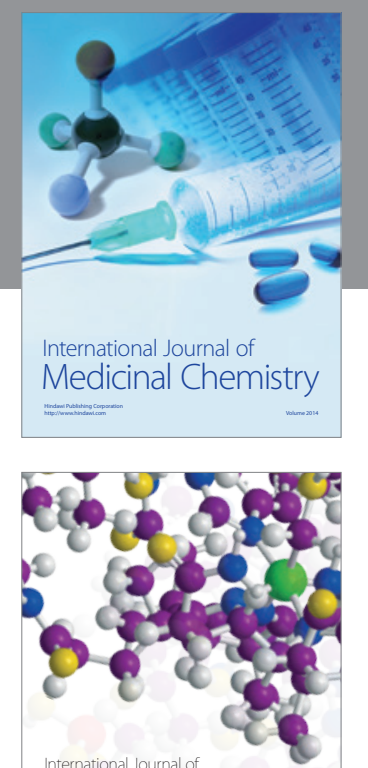

\section{Carbohydrate} Chemistry

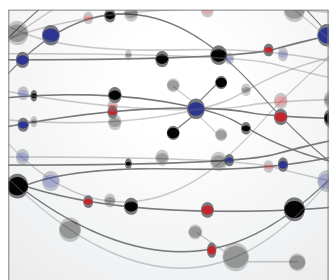

The Scientific World Journal
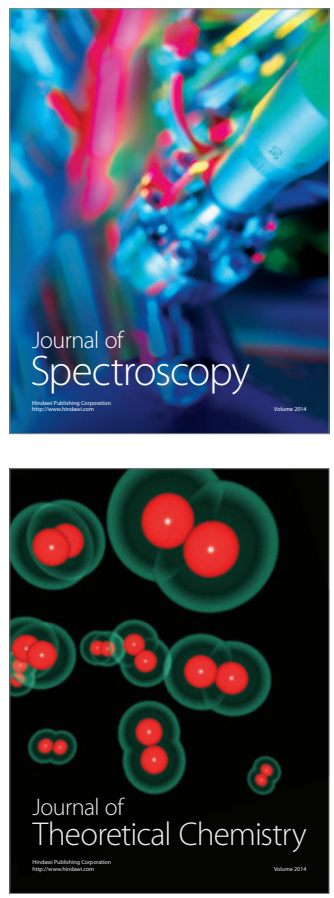
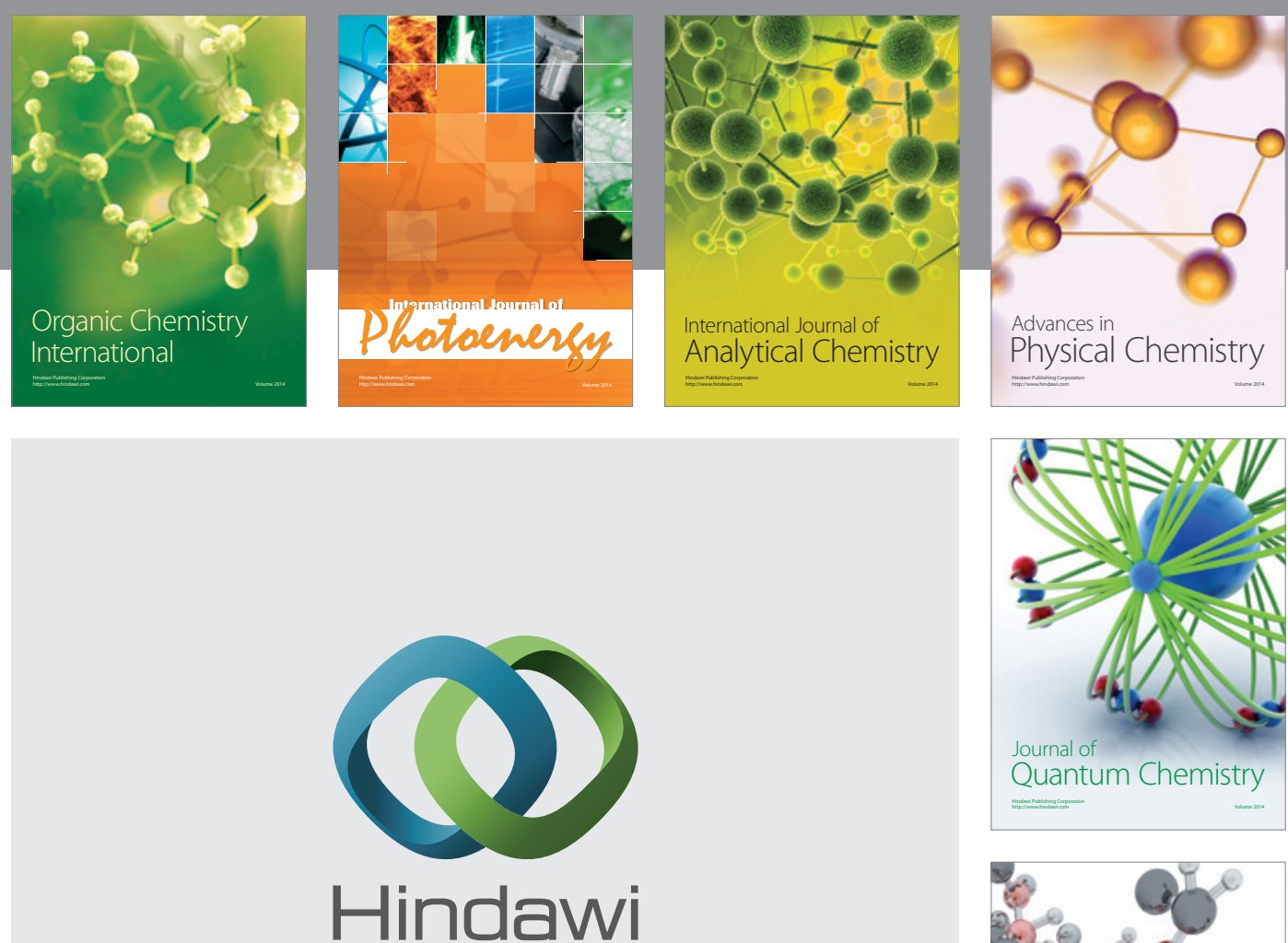

Submit your manuscripts at

http://www.hindawi.com

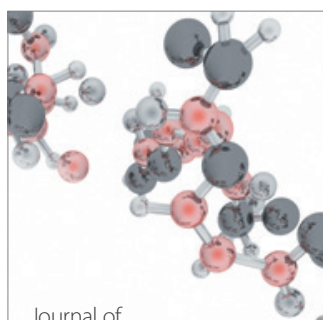

Analytical Methods

in Chemistry

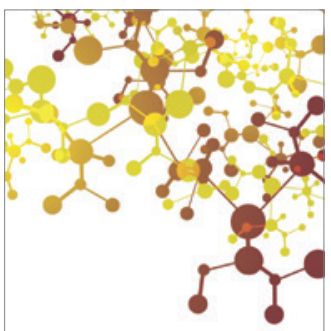

Journal of

Applied Chemistry

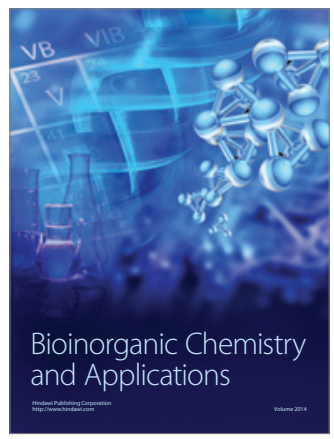

Inorganic Chemistry
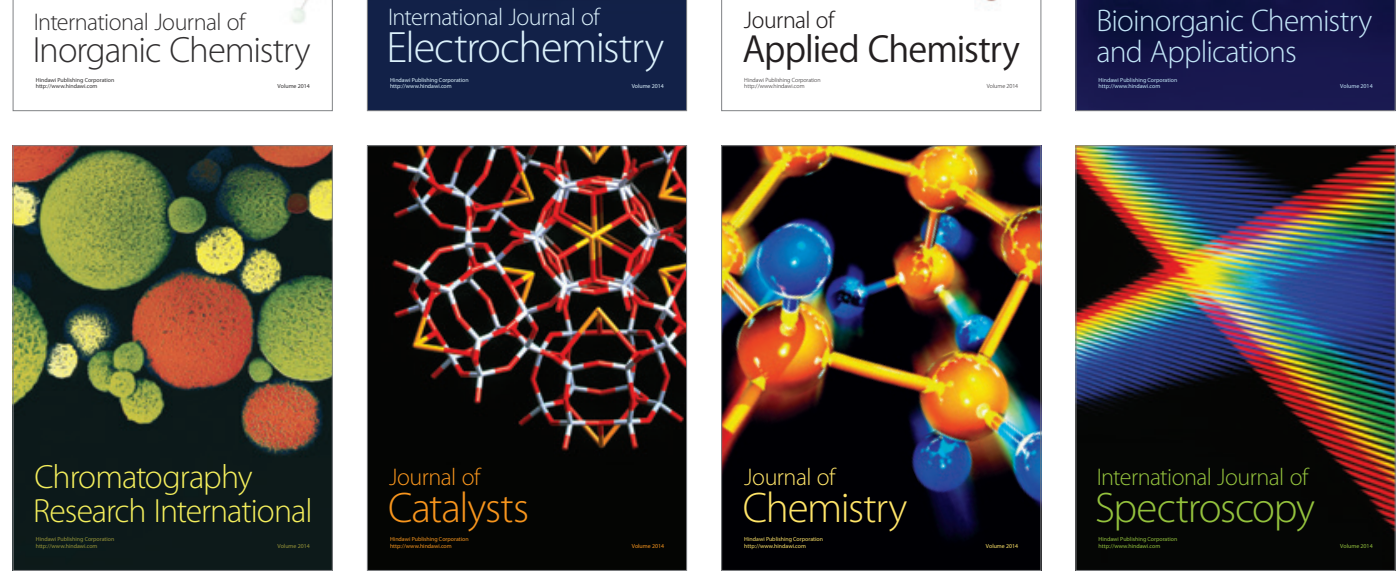